\title{
TRADISI DAN RITUAL KEMATIAN \\ WONG ISLAM JAWA
}

\author{
Suwito, Agus Sriyanto, Arif Hidayat \\ IAIN Purwokerto \\ Jl. Ahmad Yani 40-A, Telp. +62-81635624, Purwokerto-53126 \\ E-mail: suwitons@gmail.com,arif19hidayat88@gmail.com
}

Abstract: This paper reveals the tradition of Javanese people on handling the death. Javanese muslims is understood in a framework of great and little tradition and the meaning in death tradition. Those items when it is revealed and understood practically seems to have a shift. The variation in death tradition because of the distance and the evolution. There are some important highlights; first, Javanese Muslims in understanding and doing the death ritual based on a strong basic as an honour for those who alive and as a symbolic dimension with other nature. Second, Javanese Muslims know that death is a way to go back to Allah so that the everybody should be in a purified condition and still has a belief that Allah is the only one to be worshiped. The people believe that Allah is the Most Forgiving so that Muslims should pray for all the mistakes and bad deed.

Abstrak: Tulisan ini berusaha untuk mengungkap tentang tradisi kematian Wong Islam Jawa dipahami oleh pelakunya dalam framework great and little tradition, dan makna di dalam tradisi kematian Wong Islam Jawa. Dua hal tersebut, bila diungkap dan dipahami dalam tataran praktik, adakalanya memiliki pergeseran. Variasi yang muncul dalam tradisi kematian Wong Islam Jawa karena jarak yang jauh dari pusat, juga karena perubahan dari waktu ke waktu (evolusi). Dalam hal ini, ada beberapa pandangan menarik: Pertama, Wong Islam Jawa dalam memahami keyakinan dan menjalankan praktik tradisi kematian memiliki dasar yang leluhur sebagai tata cara penghormatan kepada manusia yang hidup, serta memiliki dimensi simbolik dengan alam lain. Kedua, Wong Islam Jawa dalam memaknai kematian sebagai jalan kembali kepada Tuhan sehingga harus dalam keadaan suci dan tetap memiliki keyakinan bahwa Allah SWT adalah satusatunya yang pantas disembah. Pandangannya berdasar pada Tuhan Yang Mahapengampun sehingga manusia hendaknya senantiasa berdoa untuk minta maaf atas kesalahan yang pernah diperbuat.

Kata Kuci: tradisi, Wong Islam Jawa, variasi, Tuhan, dan keyakinan. 


\section{A. Pendahuluan}

Jawa apabila dipandang dari suku maupun dari pola kehidupannya memiliki akar pengetahuan yang seolah tidak pernah habis untuk digali. Berbagai macam filosofi dari pewayangan, keyakinan, kepercayaan, tradisi, adat maupun praktik-praktik lain selalu memiliki ciri dan sudut pandang yang luhur. Hakikat kemanusiaan ini dipahami sebagai tata cara dalam hidup yang mewujud bersama komponen kebijaksanaan sejak zaman leluhur. Dimensi ini memandang hidup yang dilimpahi berkah oleh suatu kekuatan yang menopang manusia.

Nilai-nilai Jawa makin kental ketika bersentuhan dengan Islam sebagai agama raḥmatan lil 'àlamīn. Jawa pun akhirnya membentuk sejarah peradaban, dengan akulturasi budaya dan nilai-nilai yang bersatu-padu. Terlebih lagi, konsep ajaran dari Sunan Kalijaga yang terus menghidupkan nilai-nilai luhur dan melakukan pendekatan dengan cara tasawuf. Oleh karena itulah, Islam di Jawa memiliki karakter khas. Ini tampak pada: 1) varian amalan (ritual) nya, 2) pemaknaan muslim Jawa terhadap amalan (ritual). Hasil penelitian Woodward dan Salim HS (2004: 15), Mçler (2005: 7), Solikhin (2010), dan Ahyani (2012), menjadi salah satu bukti ilmiah dari karakter khas Islam Jawa tersebut yang berusaha mengeksplorasi dimensi batin dan struktur sosial secara seimbang. Faktanya, memang Jawa memiliki konsep-konsep keberhidupan terkait dengan dimensi transobjektif.

Dalam buku Rites of Passage, Van Gennep mengungkapkan bahwa masyarakat memiliki tradisi/ritus unik terkait dengan daur hidup mereka, mulai dari lahir, kanak-kanak, remaja, nikah, hingga kematian (Van Gennep, 2006: 203). Dalam konteks ini, bahwa ritual di seputar kematian seseorang di Jawa juga menjadi salah satu tradisi yang unik. Ritus ini dilakukan dengan dasar dan argumentasi yang jelas sehingga menjadi keyakinan di kalangan masyarakat, baik secara normatif (agama) maupun secara sosiologis.

Di Jawa, tradisi di seputar kematian Wong Islam Jawa dilakukan dengan dengan cara yang unik, khas, dan seringkali berbeda antara satu tempat dengan tempat lain. Pada dasarnya, memang Wong Islam Jawa membentuk keyakinan dalam spiritualitas atas pengalaman batin. Oleh karena itu, bila dicermati dengan seksama, praktik dan keyakinan dari Wong Islam Jawa jika ditinjau dari antropologi budaya ini menarik untuk diteliti guna mengungkap makna ritual secara mendalam.

\section{B. Tradisi}

Ruang lingkup tradisi tidak bisa lepas dari pembicaraan mengenai manusia dan kebudayaan dalam perilakunya di masyarakat (Subiantoro, 2010: 39). 
Sementara itu, Eliade (2002: 4), memahami tradisi sebagai pengulangan sadar at as sikap paradigmatik tertentu untuk mengungkapkan ontologi manusia, baik pada alam semesta maupun Tuhan. Lévi-Strauss (2005: 30-32) memahami tradisi sebagai bentuk pengetahuan dalam suatu masyarakat yang diwujudkan dalam kebiasaan untuk memecahkan persoalan tertent $u$ ataupun unt uk merayakan hal tertentu. Pengetahuan ini biasanya memiliki dasar kebenaran, baik secara mistis maupun rasional dengan mampu menjawab persoalan yang dihadapi.

Tradisi, dalam hal ini, terkait juga dengan interpretasi sebuah masyarakat dalam melihat realitas untuk disikapi dengan keyakinan dan kepercayaan. Tradisi terbentuk dari mitos, legenda, epos, sejarah nyata yang pernah terjadi, maupun refleksi seorang tokoh at as kehidupan yang saat itu sedang menjadi persoalan. Wujud tradisi itu sendiri sangat bermacam-macam. Mulai dari upacara keagamaan, upacara pernikahan, upacara kematian, upacara kelahiran, perayaan hari-hari tertentu, maupun tradisi dalam wujud kesenian. Biasanya, aneka macam tradisi tersebut antara daerah yang satu dengan daerah lainnya memiliki pola yang mirip, tetapi ada sedikit perbedaannya. Hal itu juga terkait dengan pengetahuan yang ada di masyarakat tersebut dan memiliki dasar makna dan filosofi tersendiri.

Menurut Lévi-Strauss (2005: 284-290), "tradisi dapat menjadi representasi dari pengetahuan suatu masyarakat." Hal ini karena di balik tradisi selalu tersimpan makna dan pandangan dunia. Menurut David Kaplan (2002: 88), "tidak banyak memang pelaksanaan upacara keagamaan tertentu dapat mengukuhkan solidaritas atau kohesi sosial, bila tidak ada penjelasan operasional" dalam hubungan fungsional dan pemeliharaan". Tiap-tiap ritus keagamaan selalu memiliki penjelasan yang menarik. Dalam hal ini, agama yang akan diikuti oleh masyarakat selalu bisa menjawab pertanyaan-pertanyaan yang dihadapi oleh masyarakat. Ketika sebuah agama tidak lagi mampu memberikan solusi atas perilaku manusia, maka perlahan-lahan akan ditinggalkan. Sebagai ahli kebudayaan, David Kaplan berusaha untuk memetakan teori antropologi dari historis umum, evolusi, fungsionalisme, difusi, adaptasi, strukt ur sosial, ideologi, strukturalisme, hingga etnosains. Tradisi dalam suat masyarakat untuk dilihat nilainya bisa ditinjau dari peran dan fungsi dengan pendekatan antropologi. Beberapa nilai seperti nilai religius, nilai moral, nilai edukatif, dan nilai spiritual yang ada di dalam tradisi hanya bisa dilihat dan dikaji dalam bentuk manifestasi, yang kemudian diinterpretasikan. Dalam pandangan semacam ini, tradisi menjadi akses yang terus ditempuh dari waktu ke waktu untuk menjaga keseimbangan dimensi kosmos alam semesta. 
Rasionalitas menjadi dasar utama pergeseran tradisi menuju kepada alasan kepraktisan yang lebih sederhana dengan tujuan tidak mengubah esensi utama. Kelangkaan elemen alam membuat manusia pada akhirnya beralih pada teknologi dengan alasan bahwa peran dan fungsinya masih sama. Teknologi baru mendorong manusia untuk mengunakan elemen yang lebih praktis dan tidak membuat rumit keadaan. Hal itu menjadi boleh dilakukan apabila ada tokoh yang membolehkan atau memberi izin. Perwujudan menyeluruh dari sebuah tradisi berusaha untuk mencari signifikasi dengan awal mula dan peran fungsi, maka apabila dua hal ini masih melekat tidak akan menjadi masalah yang berarti.

\section{Dialektika Islam dan Budaya Lokal}

Persilangan wacana Islam dengan nilai luhur lokal dalam beberapa unit memiliki kesatuan tujuan sehingga ada pandangan dunia yang bisa disatukan. Hal ini karena al-Qur'an memiliki bahasa metaforis dan simbolis dalam menjelaskan ruang dan waktu sehingga selalu bisa kontekstual dan situasi apapun. Al-Qur'an dan Hadis sebagai media untuk menyampaikan cara pandang disikapi dengan lentur oleh tokoh-tokoh Islam sehingga mampu memasuki arena institusional dari suatu kebudayaan lokal mana saja.

Bila memperhatikan dengan seksama bahwa pola penyebaran Islam yang dapat bertahan hingga sekarang adalah pola penyebaran Islam secara damai. Justru, penyebaran Islam dengan interaksi perdagangan dan sentuhan kebudayaan sampai sekarang Islam masih menjadi mayoritas seperti keberadaan Islam di Nusantara ini. Seperti yang pernah diungkapkan oleh Tjandrasasmita (2002: 19) bahwa "akibat hubungan lalulintas dari Selat Malaka ke Samudra Pasai" menyebabkan "Islam sampai ke Semenanjung Melayu" hingga akhirnya "bahasa yang mereka gunakan dengan Arab-Melayu. Pola akulturasi bahasa ini yang kemudian juga memunculkan huruf Arab Pegon seperti yang digunakan untuk menulis beberapa kitab, seperti Kitab Kuning. Huruf Arab Pegon bisa disamakan dengan huruf-huruf yang ada di dalam al-Qur'an, namun juga ada perbedaannya. Kemungkinan, bahwa huruf Arab Pegon digunakan untuk berkomunikasi pada pedagang dari Arab dengan komponen struktur makna yang dipadukan dengan struktur ujar dari masyarakat lokal Melayu.

Dalam praktik persebaran Islam memasuki Jawa tetap tidak menghilangkan unsur-unsur lokal sebagai bentuk nilai luhur. Menurut Thoha (2002: 164-165) bahwa nilai-nilai ajaran Islam yang tercermin di dalam al-Qur'an dan Hadis itu juga dapat ditransformasikan dalam kesenian lokal suatu masyarakat. Titik temunya terletak pada keindahan dan nilai luhur (kearifan lokal). Oleh 
karena itu, dalam penyebaran Islam di Jawa beberapa gagasan yang mudah diterima dan diserap tanpa ada paksaan adalah dengan akulturasi. Besarnya kepercayaan animisme dan dinamisme, serta besarnya pengaruh Hindu dan Budha menjadikan konsep tasawuf (yang menekankan pada batin) menjadi sangat mudah untuk diterima. Orang Jawa telah terbiasa untuk memahami hakikat diri, dengan segenap jiwa yang menyertainya sehingga untuk menuju kepada Allah tinggal diarahkan saja.

Teranglah bahwa Islam tersiar di Indonesia (khususnya Jawa, -pen) demikian pesat karena sesuai Islam cara tasawuf itu dengan jiwa mereka, yaitu Islam yang yang berdoa untuk orang telah mati, dan para junjungan mereka. Demikianlah nasib Islam pada abad-abad itu, bukan di Indonesia saja, tetapi seluruh dunia.

Dan kadang-kadang sebagaimana dijelaskan oleh Nicholson, yakni dengan disesuaikan tasawuf dengan suasana tempat dan maksud-maksud politik. Misalnya, ulama-ulama penyiar Islam datang ke Jawa, yang terkenal dengan sebutan Wali Sanga, yang sebagian besar guru-guru tasawuf, disesuaikan dengan kehendak politik Jawa, dipanggilkan beliau-beliau itu Susuhunan, singkatnya "Sunan" sehingga agama tumbuh dalam kalangan rakyat bawahan seketika di Demak setelah pindah ke Mataram, menjadilah Agama Kerajaan, dan para ulamanya pun diberi panggilan raja, yaitu "Sunan" (Hamka, 1993: 214).

Wong Islam Jawa selama ini telah memahami dimensi kosmos kebatinan. Oleh karena itu, mereka telah membentuk kepercayaan diri. Orang Jawa apabila diterapkan syariat seperti halnya Islam di Arab akan sangat sulit karena perbedaan latar belakang sosial dan budaya. Orang Jawa dulu tidak suka berfoyafoya dalam kesenangan, melainkan telah terbiasa dalam hidup zuhud dan arkaik. Pola kehidupan yang lebih sering mengheningkan diri memiliki kedalaman rasa pada kekuatan lain yang berada di dalam dirinya sehingga untuk mendekati dengan memunculkan kekuatan ketauhidan yang dimiliki oleh Allah. Dalam begitu, orang Jawa makin merasakan menemukan kesejatian diri, sementara di sisi lain tidak mengubah kebiasaan-kebiasaan, tradisi dan ritual yang telah ada. Yang berubah adalah sistem nilai sebagai keyakinan dan bentuk kesadaran pada alam semesta yang telah diciptakan oleh Tuhan.

Pembicaraan orang Islam Jawa menjadi lebih menarik manakala Mark R. Woodward berusaha menggali kesalehan yang dimiliki oleh orang Islam Jawa (Woodward, 1999: 167). Pandangannya tidak terlalu terstruktur seperti Clifford Geertz, melainkan berusaha untuk membuka konsep sistem nilai dari orang Islam Jawa berdasarkan pada keyakinan, kepercayaan, tingkat penghayatan, dan pendalaman materi. Agama dapat menjadi jawaban atas permasalahan 
kehidupan sehari-hari. Dalam tata keberagamaan, orang Islam Jawa mendasarkan pandangan kepada al-Qur'an dan Hadis sebagai penentuan. Namun dalam sisi yang lain, di wilayah batin, harus ditempa spiritualitasnya agar tetap memiliki perilaku yang baik seperti sabar dan ikhlas. Wong Islam Jawa menjalankan ajaran-ajaran Islam dengan meyakini al-Qur'an dan Hadis sebagai tunt unan dalam hidup, namun juga masih memandang bahwa praktik dan keyakinan yang diwariskan dari leluhur itu penting.

\section{Keyakinan dan Praktik Ritual dalam Tradisi Kematian WONG ISLAM JAWA}

\section{Menghadapi Sakaratul Maut}

Sakaratul maut oleh wong Islam Jawa dianggap sebagai proses lepasnya ruh dari dalam badan (tubuh). Secara bahasa, dipahami bahwa sakaratul maut itu kondisi sekarat (tidak bisa melakukan apa-apa) dalam menunju kematian. Ketidakberdayaan manusia dalam menghadapi sakaratul maut karena memang ruh sedang merasa tidak nyaman lagi berada di dalam tubuh karena sedang dicabut oleh malaikat. Manusia sehebat apapun tidak bisa melawan malaikat Izrail yang sedang menjalankan perintah dari Tuhan untuk mencabut nyawanya. Dalam hal ini, dapat disimpulkan bahwa sakaratul maut adalah keadaan ketidakberdayaan seseorang dalam menjalani lepasnya nyawa ketika sedang dicabut oleh malaikat Izrail.

Orang-orang di Banyumas memiliki cara-cara yang unik dalam menyikapi kerabat yang menghadapi sakaratul maut. Ada tradisi bahwa orang yang sakit harus dijenguk dan ditunggui. Pola ini dimaksudkan agar apabila terjadi hal-hal yang tidak diinginkan, maka pihak kerabat telah siap dan berada di tempat kejadian peristiwa. Dalam kondisi semacam ini, keluarga akan berkumpul, siap apabila dibutuhkan, dan mendoakan. Dalam berdoa hal utama yang dipanjatkan adalah berdoa untuk kesembuhan. Namun, bila tidak ada kesembuhan baginya, maka berdoa ${ }^{1}$ agar proses kematiannya dimudahkan (agar tidak terlalu menderita).

Sakaratul maut ditandai dengan ketaksadaran dan kesadaran dari seseorang yang hendak meninggal. Ia masih bisa melihat dan mendengar orang-

${ }^{1}$ Doa yang dipanjatkan biasanya membaca surat Yasin. Ada yang membaca hanya dari kalangan keluarga saja, namun ada pula yang sampai mengundang dari tetangga. Orang-orang percaya bahwa apabila surat Yasin dibacakan, akan memudahkan jalan yang tempuh seseorang dari sisi jiwa. Hal ini berlaku di beberapa tempat seperti di Banyumas, Kebumen, dan Boyolali. 
orang yang di sekitarnya, namun ingatannya sudah mulai kabur. Untuk membimbing orang yang sedang menjalani sakaratul maut, biasanya pihak keluarga berusaha untuk membimbing mengucapkan sahadat agar meninggal dunia dalam keadaan menyebut nama Tuhan. Orang yang meninggal dunia dalam keadaan selalu mengingat Tuhan akan selalu mendapatkan bimbingan dari cahaya Tuhan di alam kubur, maupun alam lainnya kelak.

Setelah meninggal dunia, di rumah almarhum, biasanya terdapat bendera kuning, namun ada juga yang bendera putih. Keduanya memiliki arti bahwa di rumah tersebut, ada yang meninggal dunia. Bendera kuning berarti bahwa ada yang menjadi “lelayu” yang berasal dari kata "layu”. Dalam bahasa Indonesia, layu itu artinya mati, namun lebih tepat digunakan untuk tanaman. Lelayu berasal dari bahasa Jawa pertengahan, yang berarti ada manusia yang meninggal dunia. Simbolitas layu ini kemudian ditransformasikan dan warna kuning. Sementara itu, yang menggunakan bendera putih untuk tanda bahwa di rumahnya ada yang meninggal dunia memiliki persepsi lain. Warna putih dimaksudkan sebagai wujud yang suci. Manusia yang kembali ke alam lain harus suci karena akan menghadap Tuhan. Warna putih adalah wujud warna penyerahan diri kepada Allah seperti tercermin dalam pakaian haji, juga kain yang digunakan untuk kain kafan. Begitu juga ketika seorang menyerahkan diri dalam perang, menggunakan bendera putih.

\section{Memandikan Mayit}

Mandi dalam sudut pandang orang Islam menjadi wujud kesucian. Dalam hal ini, air memegang peran dan fungsi yang sangat besar untuk memberiskan kotoran yang melekat dalam tubuh. Mandi ditinjau dari sisi kesucian dapat dilihat dari segi lahir dan batin. Secara lahir, air digunakan untuk membersihkan tubuh sehingga hilanglah segala kotoran yang melekat. Secara batin, mandi merupakan manifestasi untuk menetralkan diri. Seperti halnya komponen alam semesta, bahwa air adalah elemen yang netral. Ia bisa dibentuk apa saja, tergantung yang membentuk. Maka itu, sebelum orang menghadap kepada Tuhan, ia harus membersihkan segala kotoran melalui air.

Bagi orang-orang yang meninggal dunia dalam keadaan biasa (bukan mati syahid), ${ }^{2}$ wajib untuk mandi. Ini terkait fitrah saat ia lahir: dari yang suci kembali

${ }^{2}$ Dalam praktik, hanya orang yang mati syahid, yang tidak perlu untuk dimandikan. Orang yang mati syahid dianggap telah suci karena sedang berada di jalan Tuhan. Ia diharapkan dikubur dengan apa adanya, walaupun darahnya berlumuran akibat luka di tubuhnya. Luka tetap dibiarkan menganga sebagai bukti pengabdian kepada Tuhan Yang Maha Esa. 
ke yang suci. Manusia lahir seperti kertas kosong, maka untuk kepulangannya juga harus dibersihkan tubuhnya terlebih dulu. Dalam hal ini, air membawa nat uralitas untuk manusia sebelum kembali. Memang, seolah tak berkaitan bila ditinjau bahwa yang lepas (kembali) itu ruh, sedang jasad hanya akan berkalang tanah. Namun, perlu untuk diketahui, bahwa dimensi antara ruh dan badan masih terikat. Dengan demikian, walaupun yang dibasuh adalah badan, namun maksud untuk mensucikan mayat adalah untuk membersihkan ruh dari sifatsifat keduniawian yang pernah dijalani, dan juga pembaruan diri.

Dalam memandikan mayit di daerah Banyumas (khususnya Kecamatan Bobotsari), pihak keluarga (dengan dibantu oleh warga) biasanya menyiapkan air yang banyak dan bermacam-macam. Pertama, air leri dicampur dengan sambetan. Cara membuatnya, yakni ketika mencuci beras, maka air berubah menjadi putih seperti susu. Air sambetan dibuat dari beberapa dringo, kunir, dan bengkle yang ditumbuh sampai halus. Setelah ditumbuk sampai halus, komponen ini kemudian dimasukkan ke dalam air sehingga air tampak kekuningkuningan. Dalam persepsi ini, air leri dan air sambetan yang dijadikan satu mampu membuat sukma menjadi sejuk. Lepasnya sukma dari dalam tubuh itu sangat menyiksa dan terasa sangat panas. Kedua, air kapur barus. Air kapur barus adalah air biasa yang dicampur dengan kapur barus. Tujuan air ini untuk membunuh bakteri-bakteri kecil yang ada di kulit. Selain itu, air ini juga dimaksudkan agar mayit tidak cepat berbau busuk. Ketiga, air sabun. Air sabun digunakan untuk membersikan segala kotoran yang melekat. Ada anjuran bahwa sabun mandi yang digunakan juga sabun yang biasanya dipakai oleh almarhum ketika masih hidup (satu jenis). Keempat, air bening biasa. Air bisa bersumber dari sumur ataupun dari kali. Yang jelas, air ini terjaga kesuciannya. Selain beberapa air tersebut, di Boyolali juga disiapkan air dari merang yang telah dibakar untuk berkeramas. Air ini digunakan untuk membasuh bagian rambut agar benar-benar bersih.

\section{Mengafani Mayit}

Mengafani mayit sebenarnya hampir sama dengan memberinya pakaian. Sementara itu, pakaian untuk mayit adalah pakaian yang serba putih polos (tanpa warna lain). Pakaian putih itu juga tidak boleh ada jahitan. Yang dibolehkan hanya ikatan di beberapa bagian saja agar tidak terlepas. Ikatan itu pun ketika di dalam kubur (sebelum ditutup dengan tanah) harus dilepas terlebih dulu. Ikatan untuk mayit setelah dikafani bisanya terletak di bagian kiri tubuh agar saat mayit dimiringkan ke kanan saat penguburan menjadi mudah untuk membukanya. 
Kain kafan dipotong sesuai dengan panjang (tinggi) mayit tersebut dan diberi lebih sedikit agar mudah untuk mengikat. Biasanya, Kayim atau Modin juga akan memotong kain dalam bentuk kecil untuk dijadikan tali yang biasanya diletakkan di bagian paling bawah. Kain kafan diletakkan di keranda dengan dibentangkan satu per satu dengan tempat untuk posisi kepala mengarah kiblat. Selanjutnya, mayit diletakkan di atas kain yang telah dibentangkan tadi dan dilipat hingga menutupi seluruh tubuh tubuh, kecuali muka. Muka atau wajah tidak ditutup karena sebagai perwujudan dan sosok kemanusiaannya kelak ketika harus menghadap di alam kubur.

Dalam mengkafani mayit, juga biasanya disiapkan kapas, kapur barus halus, minyak wangi, dan beberapa keperluan lain. Kapas digunakan untuk menut up lubang telinga, lubang hidung, dan mulut apabila masih sedikit terbuka. Lubang tersebut ditutup untuk menghindari lalat (atau sejenisnya) memasuki lubang tersebut sebelum jenazah dikuburkan. Kapur barus halus biasanya ditaburkan pada kain kafan agar serangga-serangga kecil seperti semut tidak lekas mendekati mayit. Minyak wangi biasanya digunakan untuk menjadikan yang sudah berbau tidak terlalu menyengat (bau busuknya kalah dengan bau minyak wangi).

\section{Menyolati Mayit}

Shalat mayit dilakukan dengan menghadapi tubuhnya tersebut, bila dilakukan tanpa mayit (telah dikubur) disebut shalat ghā'ib. Namun, tata caranya berbeda dengan shalat pada umumnya. Shalat mayit hanya dilakukan dengan berdiri saja (tidak perlu rukuk, sujud, iktidal, dan tahyat). Dikhawatirkan bila shalat mayit sampai sujud, seolah-olah menyembah mayit yang ada di hadapannya. Dalam shalat mayit ini, biasanya dilakukan oleh tetangga dan kerabat, walau tidak secara keseluruhan. Beberapa orang perempuan juga turut menjadi makmum, bagi yang tidak sedang berhalangan.

Bagi beberapa Wong Islam di Kebumen, setelah selesai menyolati jenazah, orang-orang yang menyolati jenazah diberi uang selawat. Uang selawat adalah sejumlah uang yang diberikan kepada orang-orang yang menyolati jenazah sebagai tanda terima kasih dari pihak keluarga karena sudah berkenan menyolati dan mendoakan si mayit. Uang ini diberikan ketika jamaah telah selesai melakukan sholat jenazah dan masih dalam posisi berdiri saat berdoa setelah sholat. uang selawat biasanya dibungkus dalam amplop, dibagikan oleh seorang yang ditunjuk oleh keluarga dengan cara dimasukkan ke dalam saku baju orang yang sedang berdoa setelah selesai shalat jenazah. Besaran uang selawat ini tidak ada ketentuan umumnya. 


\section{Prosesi Sebelum mulai Mengantar}

Jenazah yang telah dimasukkan ke dalam karanda yang ditutup kain hijau bertuliskan "lā ilāha illā allāh muḥammad al-rasūlullāh", selanjutnya diantarkan ke pemakaman. Hal-hal yang dipersiapkan untuk pemberangkatan jenazah menuju pemakaman ada dua macam, yakni jika dimakamkan memaki peti dan tidak memakai peti. Jika jenazah ingin dimakamkan memakai peti, maka harus dipersiapkan peti jenazah, tanah yang diambil dari pemakaman yang dibentuk bulat-bulat (gelu) serta daun kemuning atau daun beringin. Setelah perlengkapan cukup, maka pertama yang dilakukan adalah memasukkan gelu ke dalam peti sebagai alas pipi jenazah, sebab jenazah harus tetap menempel tanah walaupun dalam peti, kemudian memasukkan daun kemuning atau daun beringin ke dalam peti sebagai alas (kasur) jenazah. Setelah itu jenazah dimasukkan dengan posisi miring dan posisi pipi jenazah menempel gelu. Kemudian peti di tutup. Jenazah yang telah dikafani dan dishalati diibaratkan seperti pengantin. Bagi almarhum sendiri, momen ini merupakan perpisahan sekaligus merupakan titik perjalanan selanjutnya ke alam lain. Alam kubur juga menjadi alam untuk pertanggungjawaban atas segala macam yang dilakukan di dunia ini. Oleh karena itu, kepergiannya ke alam kubur harus diantar sebagai bentuk penghormatan.

Bagi Wong Islam di Boyolali memiliki keyakinan bahwa jika orang yang meninggal masih memiliki anak yang belum menikah maka juga dipersiapkan anakan pohon pisang yang jumlahnya sama dengan jumlah anak yang belum menikah. Anakan pohon pisang ini nantinya akan dibawa ke makam dan diletakkan di dekat makam. Hal ini dimaksudkan sebagai perlambang bahwa anak-anaknya tetap dekat dengan orang tuanya, dan orangtua yang telah meninggal tidak perlu mengkhawatirkan anak-anak yang ditinggalkan walaupun belum dewasa. Perlengkapan lain yang perlu dipersiapkan adalah jika ada anggota keluarga yang meninggal ada yang sedang hamil, maka perlu dipersiapkan telor ayam. Telur ayam ini akan dipecahkan di pintu halaman rumah saat jenazah diberangkatkan. Hal ini merupakan simbol harapan agar anggota keluarga yang hamil tersebut tidak terganggu oleh apapun dan bisa melahirkan dengan lancar dan mudah semudah memecahkan telur.

Sebelum jenazah diantar ke pemakaman, biasanya modin atau kayim mewakili pihak akan berpidato singkat. Dalam pidato singkat, intinya, ia ingin menyampaikan apabila almarhum pernah berbuat salah kepada keluarga, kerabat, maupun masyarakat mohon untuk dimaafkan. Modin atau kayim juga menanyakan kepada seluruh orang yang ada di sekitar: bahwa jenazah tidak 
akan dikuburkan apabila masih memiliki hutang. Jenazah baru akan dikuburkan apabila sudah benar-benar bersih dari hutang juga telah dimaafkan kesalahannya selama hidup. Hal ini dimaksudkan agar kelak hal yang tampaknya sepele tersebut dapat menjadi siksa kubur yang pedih dan penuh derita.

Setelah itu, pihak keluarga akan melakukan Brobosan/Tlusupan, yang dalam tradisi orang Banyumas disebut sebagai Lodosan. Brobosan/Tlusupan dilakukan dengan cara masuk ke bawah kolong keranda jenazah dari kiri ke kanan sewaktu akan diantar ke makam. Brobosan/Tlusupan dilakukan oleh keluarga yang ditinggal untuk melepas kepergian mayit ke pemakaman. Hal dimaksudkan agar pihak yang ditinggal tidak selalu ingat kepada almarhum. Brobosan/Tlusupan dilakukan atas dasar bahwa setelah meninggal dunia, ruh masih sering datang ke rumah. Hal ini berlangsung selama 40 hari. Oleh karena itu, agar almarhum tidak muncul dalam bentuk ingatan kepada orang-orang yang ditinggal dilakukan Brobosan/Tlusupan. Boleh dikatakan, bahwa acara ini seperti pelukan terakhir sebelum mayit diantarkan ke pemakaman. Dengan perpisahan terakhir, diharapkan bahwa semua anggota keluarga telah benarbenar ikhlas melepas kepergian almarhum untuk dikuburkan.

\section{Mengantar Jenazah ke Makam}

Pada saat jenazah mau diberangkatkan, menurut Wong Islam di Boyolali ada seorang perempuan dari keluarga yang meninggal yang membawa sapu lidi dan lampu senthir (pelita). Perempuan tersebut mendahului pemberangkat an jenazah dengan menyapu halaman atau jalan sebanyak 7 langkah dari awal pemberangkatan jenazah. Hal tersebut dilakukan sebagai simbol harapan agar si Almarhum mendapatkan jalan yang bersih dan terang atau jalan yang benar dalam perjalanannya menuju alam akhirat.

Pihak keluarga membuat sawur yang terdiri dari bunga tujuh rupa, beras putih dan beras kuning, juga uang. Sawur ini tersebut ditaburkan ke atas keranda hingga meninggalkan jejak harum menuju pemakaman. Sawur dengan komponen bunga tujuh rupa yang harus dimaksudkan agar para malaikat turut mengiring kepergian (kembali) almarhum tersebut. Sementara itu, uang dan beras dimaksudkan sebagai bekal dalam perjalanannya yang masih sangat panjang. Sawur terus dilakukan hingga sampai ke kuburan. Sisa sawur akan ditaburkan ke atas kuburan, setelah jenazah dimakamkan. Selain itu, menurut Wong Islam di Boyolali bahwa sawur sebagai simbol bekal bagi si Almarhum, agar selalu mendapatkan kemurahan dari Allah. Taburan dari bunga-bunga membentuk keharuman, juga disertai dengan taburan uang. Simbolisasi ini 
menjadi wujud bahwa ada begitu banyak kemurahan yang menyertai setiap jengkal perjalanan.

\section{Pemakaman Jenazah}

Selanjutnya, jenazah tinggal dikuburkan. Jenazah dihadapkan ke kiblat dengan posisi pipi menempel tanah (sengaja diciumkan ke bumi sebagai tempatnya kembali, yakni manusia yang berawal dari tanah kembali ke tanah). Selanjutnya, butiran gethuk (gelu) diselipkan pada bagian-bagian yang berongga pada jenazah untuk keperluan cengkal agar jenazah tidak berbaik dari penciumannya ke bumi. Menurut Somad (56), jenazah sengaja diciumkan ke bumi juga mengambil hakikat dari orang yang bersujud ketika sembahyang. Dalam proses penantian yang panjang itu, ia harus bersujud. Oleh karena itu, manusia kembali kepada Allah juga harus dalam wujud bersujud (dengan mencium bumi).

Bila dalam proses penguburan tersebut melewati waktu shalat, maka sebelum diurug dengan tanah harus ada salah seorang yang azan di atas telinga jenazah tersebut. Lafadz azan sama seperti halnya azan untuk shalat lima waktu. Setelah itu, langsung saja disambung dengan iqamat. Hal ini dilakukan dengan maksud untuk turut memanggil almarhum untuk shalat. Walaupun ia telah meninggal dunia, namun posisinya belum dikubur sehingga ruhnya harus turut dipanggil untuk bersujud kepada Allah SWT. Sejatinya, walaupun ia telah meninggal dunia, namun ia belum disapa oleh Malaikat Munkar dan Nakir sehingga belum tercatat sebagai ahli kubur.

Setelah jenazah dibaringkan menghadap kiblat dalam posisi mencium bumi, maka dangka dipasang miring dengan berjajar rapat. Selain itu, beberapa yang terkait dengan kuburan juga turut dikubur seperti benda yang digunakan untuk mengukur kuburan. Dalam mengubur, ada tiga orang yang menginjakinjak tanah di kuburan, sementara yang lain mengembalikan tanah yang pernah digali ke dalam lubang. Apabila pihak keluarga sudah menyipakan batu nisan, maka akan segera dipasang. Namun, apabila pihak keluarga belum siap dengan nisan, maka hanya diambilkan sisa dangka saja.

Nisan dimaksudkan sebagai tanda bahwa tempat tersebut merupakan makam seseorang. Nisan ada yang ditulisi dengan nama orang tersebut dilengkapi dengan tanggal kelahiran hingga kematiannya. Nisan ada yang terbuat dari kayu, dan ada pula yang dibuat dari semen. Nisan atau Wong Islam Boyolali menyebutnya sebagai maesan biasa terbuat dari balok kayu. Pada bagian at as berbentuk runcing agak menumpul. Maesan tersebut nantinya ditanam di atas 
kuburan, satu di bagian arah kepala dan satunya lagi di bagian arah kaki. Nisan atau maesan tersebut sebagai tanda bahwa pada tempat tersebut telah dimakamkan seseorang. Maesan yang berada pada bagian arah kaki jenazah dituliskan nama orang yang dikuburkan di situ beserta hari, tanggal, bulan dan tahun kematian, dengan dasar tahun Jawa.

Setelah itu, kendi yang digunakan untuk membawa air tawar yang dicampuri dengan minyak cendana dan kembang telon, yang akan disiramkan di atas kuburan dan maesan. Semua itu melambangkan kesucian, kesegaran, dan keharuman nama si Almarhum. Hal lain yang dilakukan adalah dengan kelapa hijau yang masih muda. Kelapa hijau yang masih muda itu nantinya akan dibelah dan airnya akan disiramkan di atas kuburan dan belahan kelapanya juga ditelungkupkan di atas makam setelah jenazah selesai dikuburkan. Air kelapa ini melambangkan kesucian karena air kelapa adalah "air suci” karena tidak pernah tercampur oleh apapun. Selain itu, air kelapa muda juga sebagai perlambang keteguhan hati si Almarhum. Ia dianalogikan seperti halnya pohon kelapa yang berdiri kokoh, tidak mudah roboh ataupun terombang-ambing oleh angin.

Sementara itu, bagi almarhum yang memiliki putri belum menikah, maka anakan pohon pisang yang telah dibawa ke makam diletakkan di dekat makam. Hal ini dimaksudkan sebagai perlambang bahwa anak-anaknya tetap dekat dengan orang tuanya, dan orangtua yang telah meninggal tidak perlu mengkhawatirkan anak-anak yang ditinggalkan walaupun belum dewasa.

Untuk orang yang telah menggali kubur, dilarang untuk menengok ke makam sebelum tujuh langkah dari kuburan. Wong Islam Jawa meyakini apabila mereka menengok kubur sebelum tujuh langkah, maka kedatangan malaikat ke dalam kubur tersebut akan lebih cepat (yang harusnya tujuh hari dalam hitungan dunia ini). Mereka diharapkan untuk tetap lurus meninggalkan kuburan dan dianjurkan untuk langsung mandi terlebih dahulu. Bila orang yang bersentuhan dengan jenazah (dan dalam menggali kubur) tidak langsung mandi, diyakini ada beberapa penyakit yang bisa tumbuh. Bahkan, ada yang meyakini bahwa apabila tidak mandi, menyebabkan kematian pada anggota keluarganya.

\section{Takziah}

Dalam tradisi Wong Islam di Jawa memiliki rasa solidaritas tersendiri untuk orang yang sedang berduka karena ada salah satu anggota keluarganya yang meninggal dunia dengan istilah takziah. Boleh dikatakan bahwa takziah ini merupakan rasa turut berbela sungkawa atau rasa seseorang yang turut merasakan kesedihan atas kepergian almarhum. Orang dapat dinamakan takziah ke 
rumah almarhum apabila masih dalam jangka waktu 3 hari meninggalnya si Almarhum. Apabila ada orang datang ke rumah almarhum pada hari ke empat, maka tidak lagi tergolong takziah. Ia hanya tergolong menjenguk saja. Dalam menjamu tamu yang datang takziah disediakan makanan bagi para tamu. Dalam rangka menghormati tamu tersebut, tradisi yang ada di desa Dlingo, kecamatan Mojosongo kabupaten Boyolali adalah pihak keluarga menyembelih kambing yang diniatkan sebagai aqīqah bagi si mayit dan dagingnya disajikan sebagai lauk untuk menjamu tamu yang datang.

Lain halnya dengan tradisi yang ada di Kecamatan Ampel, kabupaten Boyolali. Untuk menghormati tamu yang datang takziah, pihak keluarga menyembih sapi dan dagingnya disajikan sebagai lauk hidangan yang disajikan. Hal ini juga dimaksudkan untuk menghormati tamu yang datang. Namun tradisi ini dirasa cukup memberatkan bagi keluarga, terutama bagi mereka dari kalangan yang kurang mampu. Oleh karena itulah, pada akhir tahun 1990-an, para tokoh agama dan tokoh masyarakat serta pemerintah daerah setempat sepakat untuk menghilangkan tradisi ini. Penyuluhan pun dilakukan kepada masyarakat agar jamuan kepada tamu yang datang takziah dilakukan dengan sesederhana mungkin dan tidak memberatkan keluarga. Akhirnya tradisi menyembelih kambing dan sapi ini lambat laun mulai hilang dan hanya sedikit warga yang masih melakukan tradisi ini.

Untuk masa sekarang, jamuan kepada tamu yang datang takziah secara umum pihak keluarga hanya menyediakan minuman air putih ditambah sebungkus roti, atau air putih dan permen yang disediakan dalam piring.

Tradisi di kecamatan Kebumen dan kecamatan Bulus Pesantren, pihak keluarga almarhum membagikan uang shodaqohan, yang juga sering disebut uang slametan kepada seluruh tamu yang datang takziah. Besarnya uang shodaqohan ini tidak ada ketentuan umumnya. Hal ini dilakukan dengan menyesuaikan kemampuan keluarga. Uang shodaqohan ini dimaksudkan adalah memberikan sedekah yang diatasnamakan orang yang meninggal. Oleh karena it u, pahalanya bisa diterima oleh almarhum dan bisa menjadi bekal menuju akhirat.

\section{Selamatan}

"Selamatan" berasal dari kata "selamat," yang artinya berdoa untuk minta selamat. Selamatan untuk orang yang sudah meninggal dunia memang tidak ada di dalam al-Qur'an secara pasti sehingga bukanlah sebuah kewajiban. Yang ada bahwa dianjurkan untuk anak yang saleh untuk mendoakan orangtua yang telah meninggal dunia. Orang Islam Jawa meyakini bahwa anak yang shaleh 
pahalanya tetap bisa diterima oleh orang yang telah meninggal dunia. Berdasarkan pada filosofi tersebut, orang Islam Jawa berusaha untuk mendoakan orang yang telah meninggal dunia sebagai bentuk amal berbakti karena pada kenyataannya tidak setiap orang memiliki anak (ada yang meninggal sebelum punya anak/ sebelum menikah). Namun, karena merasa bahwa si Anak ataupun pihak keluarga bukanlah ahli doa yang mustajab, mereka kemudian mengumpulkan para tetangga (masyarakat) hingga mencapai 40 orang untuk mendoakan almarhum di alam kubur. Doa dari 40 orang yang beriman dianggap setara dengan doa seorang wali (doa wali sangat mustajab karena merupakan kekasih Tuhan). Dengan menyetarakan doa dari 40 orang beriman, mereka berharap bahwa si Almarhum akan mendapatkan pertolongan di alam kuburnya dengan mengundang warga untuk selamatan bersama.

Dalam praktiknya, ada beberapa macam selamatan untuk orang yang telah meninggal dunia. Pertama, surtanah. Upacara Surtanah yang bertujuan agar arwah atau roh orang mati mendapat tempat yang layak di sisi Allah. Upacara ini merupakan kenduri yang dilakukan setelah pemakaman jenazah selesai dilakukan. Perlengkapan yang diperlukan adalah tumpeng pungkur (nasi tumpeng yang dibelah secara vertikal kemudian diletakkan saling membelakangi) ingkung ayam, sayur urap (gudangan), serta lauk-pauk. Tumpeng ungkur-ungkuran ini merupakan simbol penyempurnaan arwah. Sebagian masyarakat mengatakan bahwa tumpeng ini sengaja diposisikan saling membelakangi dengan maksud sebagai simbol perpisahan antara arwah dengan kerabatnya. Di samping itu juga, tumpeng sebagai simbol keikhlasan keluarga terhadap kerabatnya yang sudah meninggal. Tumpeng membelakangi sebagai perlambang bahwa mereka tidak akan lagi saling melihat atau saling bertemu.

Kedua, selamatan tujuh hari. Selamatan tujuh hari dilakukan selama tujuh hari berturut-turut. Selamatan ini biasanya dilakukan saat malam hari. Ada yang seusai Magrib, ada pula yang seusai shalat Isya. Ada juga desa yang melakukannya seusai shalat Asar. Artinya, sebenarnya tidak ada keharusan yang pasti antara malam dan siang, yang jelas waktunya dilakukan tujuh hari dari mulai jenazah dikuburkan dengan membaca tahlil dan surat Yāsīn. Di beberapa lingkungan pondok pesantren, tidak hanya membaca membaca tahlil dan surat yasin berturut-turut, melainkan juga membaca al-Qur'an sampai khatam 30 juz. Untuk membaca al-Qur'an 30 juz ini hanya dipilih beberapa orang yang benarbenar fasih membaca al-Qur'an dan di-"beri tugas" untuk membaca al-Qur' an selama 7 hari sampai khatam. Bagi orang desa yang sangat agraris, rasanya susah untuk menemukan orang yang hafal al-Qur'an dan mampu membaca secara fasih. Maka itu, budaya ini tidak terlalu menyebar di kalangan Wong Islam Jawa 
secara umum. Dengan adanya selamatan selama tujuh hari ini dimaksudkan agar ia tetap dalam keadaan beriman kepada Allah SWT sehingga tetap mengingat Allah SWT. Selama tujuh hari, manusia di dalam kubur akan ditanya keimanannya oleh malaikat.

Ketiga, selamatan 40 hari. Selamatan 40 hari adalah selamatan untuk almarhum yang telah meninggal dunia selama 40 hari, terhitung dari saat dia meninggal dunia, bukan dari mulai dikuburnya.

Keempat, selamatan 100 hari (Nyatus). Selamatan 100 hari (nyatus) adalah selamatan untuk almarhum yang telah meninggal dunia selama 100 hari, terhitung dari saat dia meninggal dunia, bukan dari mulai dikuburnya.

Kelima, Selamatan Setahun (Mendak Pisan). Selamatan tahun adalah selamatan untuk almarhum yang telah meninggal dunia selama satu tahun, terhitung dari saat dia meninggal dunia, bukan dari mulai dikuburnya. Cara menghitungnya biasanya dua tahun setelah kematian dari waktu meninggalnya si Almarhum, yang kemudian ditambah tiga hari.

Keenam, Selamatan Dua Tahun (Mendak Pindo). Selamatan dua tahun atau dikenal sebagai mendak pindo adalah adalah selamatan untuk almarhum yang telah meninggal dunia selama dua tahun, terhitung dari saat dia meninggal dunia, bukan dari mulai dikuburnya. Cara menghitungnya biasanya dua tahun setelah kematian dari waktu meninggalnya si Almarhum, yang kemudian ditambah satu minggu.

Ketujuh, Selamatan Nyewu. Selamatan nyewu adalah selamatan untuk almarhum yang telah meninggal dunia selama 1000 hari, terhitung dari saat dia meninggal dunia, bukan dari mulai dikuburnya. Biasanya, sebelum selamatan nyewu, pihak keluarga datang terlebih dulu ke makam untuk bersih-bersih, walau ada juga yang datangnya esok setelah selamatan nyewu sekalian menyiramkan bunga yang telah didoakan saat selamatan.

\section{Sadranan}

Bulan sadran juga dikenal sebagai Sya'ban atau Ruwah. Pada bulan ini dipercaya bahwa pintu langit sedang dibuka, sekaligus juga dibuka rahmat oleh Allah SWT. Pada bulan ini juga dipercaya bahwa orang yang shalat dan meminta ampunan kepada Allah SWT akan dimaafkan beberapa dosanya. Dengan kata lain, bulan ini menjadi bulan pengasih untuk beberapa dosa yang telah dilakukan oleh manusia sehingga pada bulan ini beberapa orang Islam Jawa berusaha untuk datang ke makam-makam leluhur ataupun kerabatnya untuk berdoa memohon agar si Almarhum diampuni beberapa dosa-dosanya. Hal ini 
kemudian menjadi tradisi bagi orang Islam Jawa bahwa pada bulan sadran untuk membersihkan kuburan desa secara bersama-sama (gotong royong).

Sadranan dalam konteks bersih kubur ini pada zaman dulu dilengkapi dengan nasi tumpeng. Ada yang membuat nasi tumpeng kemudian dimakan bersama setelah bersih kubur selesai dan didoakan oleh ulama. Ada pula yang pada pagi hari hingga siangnya bersih kubur, kemudian malamnya shalat tasbih setelah itu tahlil bersama di masjid atau musala, barulah kemudian memakan bersama nasi tumpeng. Akan tetapi, dalam praktik perkembangan hingga masa sekarang, nasi tumpeng untuk sadranan ini sudah mulai ditinggalkan (hanya beberapa daerah yang masih). Adapun alasan lain dipilihnya bulan Sya'ban atau Ruwah ini karena pada saat bulan puasa (Ramadan) orang yang telah dikubur akan diliburkan dari segala siksa. Ia baru akan mendapatkan siksa lagi setelah hari raya. Oleh karena itu, menjelang bulan puasa (Ramadan), makam perlu dibersihkan dan ia perlu didoakan untuk bisa beristirahat dengan tenang saat bulan Ramadan. Dalam hal ini, manusia tidak ada yang sempurna sehingga siksa kubur pun selalu ada.

\section{E. Makna Kematian Wong Islam JaWa}

Dalam perspektif Wong Islam Jawa, kematian merupakan jalan kembali kepada Tuhan. Dengan kata lain, walaupun manusia tersebut telah mati, tetapi ia tidak benar-benar mati. Yang mati adalah tubuhnya, sementara ruhnya masih hidup. Ruh melakukan perjalanan ke alam lain, yakni ke alam kubur. Mereka mendsarkan pandangannya seperti yang tertera dalam surat al-Mu'minūn ayat 115 berikut ini.

Artinya: Maka Apakah kamu mengira, bahwa sesungguhnya Kami menciptakan kamu secara main-main (saja), dan bahwa kamu tidak akan dikembalikan kepada kami?

Selain itu, juga ada surat an-Nāzi'āt ayat 44 yang juga menegaskan bahwa manusia tidaklah mati sepenuhnya, melainkan kembali kepada Allah seperti yang tertera berikut ini.

Artinya: kepada Tuhanmulah dikembalikan kesudahannya (ketentuan waktunya).

Dasar tersebut menjadi keyakinan bagi wong Islam Jawa untuk memahami bahwa orang yang telah mati itu tidak tamat begitu saja dalam keadaan membusuk. Yang membusuk hanya tubuh, sementara ruhnya tidak mati. Hal tersebut karena ruh manusia berasal dari Tuhan, seperti halnya ruh Nabi Adam AS yang ditiupkan oleh Allah SWT ke dalam tanah liat. Tempat tinggal manusia awalnya di surga, namun karena tidak bisa menghadapi godaan setan, maka harus me- 
ninggalkan surga. Oleh karena itu, untuk bisa kembali ke surga, manusia harus senantiasa menyembah Allah dan banyak bertaubat. Manusia untuk kembali harus terpisah dari tanah liat yang membungkusnya, yakni tulang dan segumpal daging yang dialiri darah.

Titik pusat keseimbangan alam semesta ini berada pada manusia. " $\mathrm{Di}$ dalam Islam, aktivitas ragawi manusia menjadi bentuk kesadaran spritual", yakni melalui praktik salat untuk tetap menyangga langit. Dunia ini akan kiamat apabila sudah tidak ada manusia yang shalat, yang artinya tiang alam semesta telah runtuh. Makna simbolik dan filosofis ini terbentuk karena manusia sebagai pusat keseimbangan. Oleh karena itu, kehidupan manusia di bumi ini, dari lahir sampai dengan mati begitu penting peranannya untuk kelangsungan alam semesta. Melalui tubuh, manusia dapat membangun, namun juga bisa saja merusak. Dalam hal ini, karena manusia telah berjanji dan sanggup menjadi wakil Allah SWT, maka segala sifat dan perbuatannya akan dinilai. Sebagai wujud bentuk keadilan dari Allah SWT, telah disiapkan surga dan neraka. Namun, sebelum manusia dihisab amal dan perbuatannya dan dimasukkan ke salah satu tempat tersebut, manusia juga harus mempertanggungjawabkan perbuatannya di alam kubur, setelah terpisah dari tubuh.

Wong Islam Jawa dalam hal kematian juga meyakini adanya moksa. Orang yang mampu untuk moksa adalah orang yang telah mencapai kesempurnaan sehingga seluruh tubuhnya menjadi cahaya. Dalam artian, bahwa cahaya spiritualitasnya mampu menjadikan tanah liat sebagai cahaya sepenuhnya. Tubuhnya (tanah liat) menjadi suci dengan cahaya di dalam dirinya yang mampu membentuk kesatuan. Oleh karena itu, tidak ada jejak makam, maupun jejak kematiannya. Yang ada hanya jejak hilangnya dirinya ke alam lain untuk kembali sepenuhnya. Orang-orang yang mencapai taraf seperti ini setara dengan wali atau aulia, yang telah memahami ilmu martabat tujuh.

Dalam pandangan wong Islam Jawa, cahaya maupun api memberikan penerangan at as kegelapan yang menyelimuti manusia. Tanah, air, dan udara itu gelap, maka butuh api atau cahaya untuk menyinarinya. Api yang berasal dari setan itu panas sehingga membuat spiritualitas itu juga panas, maka wujudnya dengan tingkah laku yang buruk. Sementara itu, cahaya yang berasal dari Tuhan tidak terlalu panas sehingga apabila bisa mengendalikan diri akan menjadi perbuatan mulia. Setiap cahaya yang berasal dari Tuhan jika tidak disadari sebagai kebaikan, maka juga akan berakibat buruk. Oleh karena itu, usaha untuk bangkit dari kegelapan ini, manusia harus berhati-hati, mampu mengendalikan hawa nafsu, dan tetap menjaga spiritualitasnya. 
Wong Islam Jawa juga percaya akan adanya malaikat. Mereka percaya adanya malaikat maut, yakni Malaikat Izrail yang memang ditugaskan oleh Allah untuk mencabut nyawa manusia dari dalam badan. Setelah manusia berada di alam kubur, ada juga Malaikat Munkar dan Nakir yang bertugas untuk menyapa manusia yang baru saja meninggal dunia dengan beberapa pertanyaan seperti: Siapa tuhanmu? Siapa nabimu? Apa agamamu? Apa kitabmu? Dan di mana kiblatmu? Untuk manusia yang beriman, pertanyaan-pertanyaan ini dapat dijawab dengan mudah. Manusia yang memiliki pengetahuan spiritual mendalam ketika masih hidup, maka pengetahuan tersebut abadi. Dalam hal ini, pengetahuan manusia dari segi akal (pengetahuan rasional) akan turut terkubur bersama jasad. Kecerdasan-kecerdasan berpolitik, berdagang, maupun kemampuan memikirkan angka-angka secara rasional akan hilang begitu saja. Pengetahuan-pengetahuan keduniawian tidak bisa memasuki alam kubur. Pengetahuan yang tetap abadi adalah pengetahuan spiritual yang dibangun at as pengendalian hawa nafsu dan rasa kebaktian kepada Tuhan. Pengetahuan spiritual itu termanifestasi dalam amal kehidupan sehari-hari. Sebagai contoh, orang berperilaku dengan mendasarkan pada al-Qur' an dan Hadis atau orang yang sembahyang dengan ikhlas, maka spritualitasnya telah terbentuk dengan mengarah pada rasa mendekati Tuhan sehingga dapat dengan mudah menjawab pertanyaan dari Malaikat Munkar dan Nakir tersebut.

Dalam keyakinan Wong Islam Jawa, orang yang telah mati itu akan berada di alam kubur. Bagi orang yang memiliki amal pahala (tidak mendapatkan siksa), maka ia akan mengalami tidur yang sangat panjang hingga kiamat. Begitu pula dengan orang yang hidupnya dipenuhi dengan perbuatan buruk, maka ia akan mendapatkan siksa hingga kiamat. Datangnya kiamat akan menghancurkan alam semesta, namun ruh manusia dibangkitkan kembali untuk dihisab amal perbuatannya. Kiamat itu sendiri terjadi setelah malaikat Israfil meniup terompet sebagai tanda bahwa sudah tidak ada lagi orang yang beriman.

\section{F. Simpulan}

Dari fenomena yang telah dipaparkan pada uraian sebelumnya, maka ada beberapa hal yang bisa disimpulkan dalam tulisan ini. Pertama, bila dipahami dengan seksama, bahwa keyakinan dan tradisi kematian Wong Islam Jawa memiliki nilai luhur yang dapat membuat manusia bisa memahami asal-usulnya, yakni dari tanah. Tradisi kematian Wong Islam Jawa juga merupakan penghormatan atas manusia yang telah hidup (menjadi khalifah) di dunia ini. Dengan seperangkat pengetahuan tersebut, praktik dan tradisi kematian Wong Islam Jawa selalu memiliki unsur simbolik dengan alam lain. Kedua, Wong Islam Jawa 
dalam memaknai kematian sebagai jalan kembali karena hakikat manusia itu berasal dari Tuhan. Untuk kembali, manusia tidak membawa apa-apa kecuali mempertanggungjawabkan perbuatannya selama ini. Untuk manusia yang telah mendapat pengetahuan spiritual, akan selalu mendapatkan cahaya dari Tuhan. Adapun untuk kembali, manusia harus dalam wujud yang suci, dan apabila banyak dosa maka anak yang shaleh harus senantiasa mendoakannya karena Tuhan Mahapengampun.

\section{Daftar Pustaka}

Ahyani, Shidqi. 2012. "Islam Jawa: Varian Keagamaan Masyarakat Muslim dalam Tinjauan Antropologi." Jurnal Salam 15.1 (2012).

Eliade, Miracle. 2002. Mitos Gerakan Kembali Yang Abadi: Kosmos dan Sejarah (The Myth of the Eternal or Cosmos and History) Terj. Cuk Ananta. Yogyakarta: Ikon Teralitera.

Hamka. 1993. Tasawuf Perkembangan dan Pemurniannya. Jakarta: Pustaka Panjimas.

Kaplan, David. 2002. Teori Budaya (The Theory of Culture) Terj. Landung Simat upang. Yogyakarta: Pustaka Pelajar.

Lévi-Strauss, Claude. 2005. Antropologi Struktural (Anthropologie Structurale) Terj. Ninik Rochani Sjams. Yogyakarta: Kreasi Wacana.

Möller, André. 2005. Ramadan in Java: The Joy and Jihad of Ritual Fasting. Vol. 20. Almqvist \& Wiksell International.

Solikhin, Muhammad. 2010. Misteri Bulan Suro Perspektif Islam Jawa. Penerbit Narasi.

Subiantoro, Slamet. 2010. Antropologi Seni Rupa: Teori, Metode \& Contoh Telaah Analitis. Surakarta: UNS Press.

Tjandrasasmita, Uka. 2000. Pertumbuhan dan Perkembangan Kota-kota Muslim di Indonesia: dari Abad XIII sampai XVIII Masehi. Kudus: Menara Kudus.

Thoha, Zainal Arifin. 2002. Eksotisme Seni Budaya Islam: Khazanah Peradaban dari Serambi Pesantren. Yogyakarta: Bukulaela.

Van Gennep. 1977. The Rites of Passage. London: Pinguins.

Wawancara dengan Somad (Ketua RT Desa Banjarsari, Rt 04/7, Kecamatan Bobotsari) pada 10 Juni 2014.

Woodward, Mark R. 1999. Islam Jawa: Kesalehan Normatif Versus Kebatinan (Normatif Piety and Mysticism) Terj. Hairus Salim HS. Yogyakarta: LKiS. 